DOI: https://doi.org/10.24127/ajpm.v10i2.3559

\title{
ANALISIS AKTIVITAS BELAJAR SISWA DALAM PEMBELAJARAN MATEMATIKA DENGAN METODE BRAINSTORMING TIPE ROUND ROBIN
}

\author{
Baiduri $^{{ }^{*}}$, Arif Hidayatul Khusna ${ }^{2}$, Erika Dewi Saraswati ${ }^{3}$ \\ ${ }^{1 * 2,3}$ Universitas Muhammadiyah Malang, Malang, Indonesia \\ *Corresponding author \\ E-mail: $\quad$ baiduri@umm.ac.id ${ }^{1 *}$ \\ khusna@umm.ac.id ${ }^{2)}$ \\ erikadewisaraswati20@gmail.com ${ }^{3)}$
}

Received 13 February 2021; Received in revised form 15 June 2021; Accepted 29 June 2021

\begin{abstract}
Abstrak
Penelitian ini bertujuan untuk menganalisis aktivitas belajar siswa dalam pembelajaran matematika dengan metode brainstorming tipe round robin. Aktivitas belajar siswa yang menjadi fokus dalam penelitian ini adalah visual activities, oral activities, listening activities, writing activities, drawing activities, motor activities, mental activities, emotional activities. Jenis penelitian yang digunakan adalah teaching experimental dengan pendekatan kualitatif. Subjek penelitian ini adalah siswa kelas VII SMP sebanyak 9 siswa terdiri dari 3 siswa laki-laki dan 6 siswa perempuan. Subjek berasal dari SMPN Mojokerto sebanyak 6 siswa dan Pondok Jombang 3 siswa. Teknik pengumpulan data yang digunakan dalam penelitian ini menggunakan observasi dan dokumentasi dari tiga kali pertemuan dalam pembelajaran matematika. Observasi digunakan untuk data aktivitas siswa yang diperoleh dari kegiatan siswa dalam penerapan metode brainstorming tipe round robin, sedangkan dokumentasi digunakan untuk mendapatkan data-data tertulis yang dipergunakan dan mengabadikan hasil pekerjaan siswa dari lembar kerja kelompok yang mereka kerjakan. Instrumen yang digunakan adalah Rencana Pelaksanaan Pembelajaran (RPP), Lembar Kerja Kelompok (LKK), dan lembar observasi. Hasil yang didapat dari penelitian ini bahwa aktivitas belajar siswa dalam pembelajaran matematika dengan metode brainstorming tipe round robin dikategorikan sangat baik pada aktivitas visual, mendengarkan, dan emosional. Sedangkan pada aktivitas oral, menulis, emosi, motor, dan menggambar dikategorikan baik.
\end{abstract}

Kata kunci: Aktivitas belajar siswa; metode brainstorming tipe round robin; pembelajaran matematika.

\begin{abstract}
This study aims to analyze student learning activities in learning mathematics with the round robin type brainstorming method. Student learning activities that are the focus of this research are visual activities, oral activities, listening activities, writing activities, drawing activities, motor activities, mental activities, emotional activities. The type of research used is experimental teaching with a qualitative approach. The subjects of this study were 9 students of grade VII junior high school students consisting of 3 male students and 6 female students. The subjects came from SMPN Mojokerto with 6 students and Pondok Jombang 3 students. The data collection technique used in this study were observation and documentation from three meetings in learning mathematics. Observation is used for student activity data obtained from student activities in the application of the round robin type brainstorming method, while documentation is used to obtain written data used and perpetuate the results of student work from the group worksheets they are working on. The instruments used are Learning Implementation Plans (RPP), Group Worksheets (LKK), and observation sheets. The results obtained from this study that students' learning activities in learning mathematics with the round robin type brainstorming method are categorized very well in visual, listening, and emotional activities. Meanwhile, oral, writing, emotional, motor, and drawing activities were categorized as good.
\end{abstract}

Keywords: Mathematics learning; round robin type brainstorming method; student learning activities 
DOI: https://doi.org/10.24127/ajpm.v10i2.3559

\section{PENDAHULUAN}

Matematika merupakan salah satu pelajaran wajib yang diajarkan pada tingkatan sekolah dasar, sekolah menengah, sekolah atas dan salah satu komponen dari pendidikan nasional (Ayuwanti, 2017; Rohmah \& Herdiman, 2017). Oleh karenanya kualitas pembelajaran matematika merupakan hal yang sangat penting. Salah satu faktor penentu mutu pendidikan ialah guru. Guru menjadi peran terdepan untuk mewujudkan sumber daya manusia yang berkualitas (Werdiningsih \& Sari, 2016). Melalui guru akan dihasilkannya peserta didik yang kualitasnya baik dalam akademisnya, berkeahlian, memiliki emosional yang baik, moral, dan spiritual (Srinalia, 2015).

Salah satu indikator kualitas dari pembelajaran adalah keterlibatan siswa dalam proses pembelajaran. Keterlibatan siswa dapat dilihat dari aktivitas dan outputnya adalah hasil belajar. Hasil evaluasi terhadap prestasi siswa dalam bidang matematika hasil survei TIMSS pada tahun 2011, Indonesia menempati posisi ke 38 dari 42 negara dengan skor rata-rata sebesar 386 di bawah rata-rata skor TIMSS yang berkisar di skor 500 (Hewi \& Shaleh, 2020). Lebih lanjut tentang aktivitas siswa, Hanida, Suryani, \& Sukmawati (2016) menyatakan bahwa hasil persentase dari aktivitas belajar siswa pada pengamatan awal dikategorikan rendah dan tidak berani aktif dalam aktivitas selama pembelajaran berlangsung (Aliwanto, 2017). Oleh karenanya perlu didesain pembelajaran yang melibatkan peran aktif siswa, dimana siswa dijadikan sebagai subjek belajar dalam suatu pembelajaran. Pembelajaran haruslah ada interaksi dari guru dan siswa yang selaras guna mencapai tujuan belajar yang diharapkan (Ulfaira, Jamaludin, \& Septiwiharti, 2014). Oleh karenanya perlu dilakukan perubahan metode pembelajaran yang mendorong peningkatan aktivitas belajar siswa (Aliwanto, 2017).

Rahmayanti (2016) menyatakan siswa dikatakan aktif apabila ada siswa yang merasa dirinya mampu berinteraksi dengan guru, lingkungan (teman kelas), bertanya dan mempertanyakan, menjelaskan, dan lain-lain. Keaktifan siswa ini melibatkan dan mengasah ranah kognitif, afektif, dan psikomotorik yang dipunyai masing-masing siswa. Salah satu solusi digunakannya metode pembelajaran yang baru, lebih menyenangkan, dan memberikan motivasi pada siswa dalam pembelajaran untuk adanya peningkatan aktivitas belajar siswa (Eka Fatmahwati, 2014). Keterlibatan siswa mengacu pada sejauh mana keaktifan siswa, minat, dan semangat yang ditunjukkan siswa ketika mereka mengikuti proses pembelajaran yang menjadi salah satu faktor dalam proses pembelajaran (Reeve, 2012; Trowler, 2010).

Beberapa penelitian yang mengkaji peningkatan aktivitas siswa dalam pembelajaran dengan model kooperatif (Ayuwanti, 2017; Azizah, 2013; Mufidah, Effendi, \& Purwanti, 2013; Nurhidayah, 2015), melalui pembelajaran tematik (Hanida, Suryani, \& Sukmawati, 2016), dengan pendekatan PBL (Rahmadani N., 2018), metode bermain peran (Zulfa \& Zahroul, 2016; Ulfaira dkk, 2014). Sedangkan penelitian yang terkait dengan metode Brainstorming round robin (Rohmah \& Herdiman, 2017) mengkaji koneksi dan kemandirian dan kooperatif tipe round robin (Ayu dkk, 2018), metode brainstorming pada pelajaran Ekonomi (Wardani, 2016). 
Berdasarkan penelitian terdahulu belum ada penelitian yang secara khusus mengkaji aktivitas siswa dalam pembelajaran matematika yang menggabungkan metode brainstorming tipe round robin. Menurut Wardani (2016) penerapan metode pembelajaran brainstorming dapat meningkatan aktivitas belajar siswa. Amin (2017) menyatakan bahwa konsep dari metode brainstorming adalah upaya dalam proses pembelajaran yang menarik dan mampu mendorong siswa dalam berperan aktif saat belajar dan menyampaikan pendapatnya dengan tujuan untuk dikumpulkan segala gagasan, pendapat, ide dalam menentukan, memilih dari berbagai pernyataan yang telah dikemukakan sebagai jawaban yang paling sesuai dan benar dari pertanyaan yang berkaitan pada pembelajaran tersebut.

Pemilihan metode Brainstorming Tipe Round Robin ini memiliki tujuan untuk memberi kesempatan pada setiap peserta didik dalam mengungkapkan ide, mengumpulkan segala gagasan sebagai jawaban yang paling benar dengan cara yang efektif untuk memberikan dorongan dalam berperan aktif pada individu yang pemalu (atau tidak tertarik) untuk berbicara agar yang dominan tidak mengambil alih saat sesi Brainstorming diterapkan. Setiap anggota kelompok secara bergiliran merespon pertanyaan dan pernyataan dalam aktivitas belajarnya (Ayu, Yusmin, \& BS., 2019).

Ada delapan macam aktivitas belajar siswa yang dilakukan guna mencapai target belajar yang maksimal, yakni : visual activities, oral activities, listening activities, writing activities, drawing activities, motor activities, mental activities, emotional activities (Paizaluddindan \& Ermalinda, 2014) yang menjadi fokus pada penelitian ini.
Penelitian ini memiliki tujuan untuk menganalisis aktivitas belajar siswa dalam pembelajaran matematika dengan metode Brainstorming Tipe Round Robin.

\section{METODE PENELITIAN}

Jenis penelitian menggunakan teaching experimental dengan pendekatan kualitatif. Teaching experimental untuk membuat gambaran tentang kemajuan siswa perkembangan aktivitas belajar siswa dengan metode brainstorming tipe round robin dan menghasilkan efek pencapaian yang dilakukan lebih dari satu kali (Sheng, 2019). Teaching experimental kualitatif digunakan untuk menganalisis perkembangan aktivitas belajar siswa dengan penerapan metode brainstorming tipe round robin.

Untuk mencapai tujuan penelitian, tahapan kegiatan penelitian adalah perencanaan/persiapan, pelaksanaan dan pelaporan. Aktivitas pada tahap persiapan yaitu menyusun instrumen penelitian yaitu Rencana Pelaksanaan Pembelajaran (RPP) dan Lembar Kerja Kelompok (LKK) serta lembar observasi. Tahap pelaksanaan didahului dengan menyampaikan ke peserta didik tentang tujuan penelitian dilanjutkan melaksanakan kegiatan pembelajaran dan pengumpulan data. Pelaksanaan dilakukan pada 15 Juli 2020 - 17 Juli 2020 di rumah secara offline karena pada masa pandemic virus corona. Kegiatan pembelajaran dilakukan sebanyak tiga kali pembelajaran. Sedangkan pada tahap pelaporan melakukan analisis data sesuai dengan tujuan penelitian dan menulis naskah publikasi.

Subjek penelitian adalah siswa kelas VII SMP sebanyak 9 siswa terdiri dari 3 siswa laki-laki dan 6 siswa perempuan dari tempat les rumahan/ 
bimbingan belajar rumahan yang berasal dari sekolah yang berbeda. Pemilihan siswa kelas VII dikarenakan materi bilangan bulat dan pecahan diajarkan pada semester ganjil kelas VII dan dari 9 siswa tersebut memiliki sikap aktif dan pasif saat proses belajar berlangsung.

Data yang dibutuhkan dalam penelitian ini adalah aktivtas belajar siswa yang diperoleh melalui observasi dan dokumentasi pada setiap kelompok selama proses pembelajaran. Observasi dilakukan oleh dua observer pada masing-masing kelompok. Sedangkan dokumentasi diperoleh dari jawaban tertulis dalam mengerjakan Lembar Kerja Kelompok (LKK) dalam penerapan metode brainstorming tipe round robin.

Instrumen yang digunakan pada penelitian ini yaitu perangkat pembelajaran dan lembar observasi. Instrument yang sudah divalidasi oleh validator berupa lembar observasi, Rencana Pelaksanaan Pembelajaran (RPP), dan Lembar Kerja Kelompok (LKK). Rencana Pelaksanaan Pembelajaran (RPP), dan Lembar Kerja Kelompok (LKK) digunakan pada penelitian untuk menerapkan metode brainstorming tipe round robin pada pembelajaran matematika. Lembar observasi digunakan pada penelitian ini untuk mengobservasi aktivitas belajar siswa yang disesuaikan dengan langkahlangkah brainstorming tipe round robin dan dilakukan oleh 2 observer.

Teknik analisis data dalam penelitian ini menggunakan tahapan Hypothetical Learning Trajectory (HLT), yakni : siswa dibentuk dalam kelompok kecil setelah itu diambil data untuk dilakukan penyesuaian yang ada saat pembelajaran, dan HLT akan digunakan pada penerapan teaching experiment dan hasil pengumpulan data dari setiap instrumen pada penelitian didapat dari lembar observasi (Budiyono, Kusumaningsih, \& Albab, 2019). Hypothetical Learning Trajectory (HLT) mempertimbangkan pengetahuan yang dimiliki oleh siswa. HLT sendiri menciptakan suatu hipotesis atau dugaan guru tentang bagaimana siswa belajar. Langkahlangkah analisis data dengan pendekatan kualitatif pada penelitian Rijali (2019) adalah :

1. Pengumpulan data dilakukan saat penilitian yakni berupa hasil obervasi dari observer melalui lembar observasi.

2. Reduksi data, yaitu sebagai proses pemfokusan data kasar di lapangan langsung pada waktu pengumpulan data yang sudah ditentukan. Misal : memilih hasil pengerjaan LKK untuk dikaitkan dengan aktivitas belajar siswa, memilih foto yang sesuai untuk dimasukkan ke dalam laporan. Dengan demikian reduksi data dimulai sejak peneliti memfokuskan fokus penelitiannya.

3. Penyajian data, yaitu proses pembuatan laporan hasil peneilitian yang telah dilakukan dari pengumpulan data untuk dianalisis selanjutnya.

4. Penarikan kesimpulan, yaitu proses dalam pengumpulan data yang dideskripsikan yang didapat dari dari hasil analisis berupa semua hasil dari lembar observasi setiap kelompok dalam melihat aktivitas siswa saat melakukan metode brainstorming tipe round robin dalam pembelajaran matematika.

Data yang diperoleh dianalisis secara deskriptif dengan menggunakan rumus yang digunakan Eko Nugroho (2016)

$N=\frac{\sum \text { skor yang diperoleh } \times 100 \%}{\sum \text { skor maksimal }}$ 
DOI: https://doi.org/10.24127/ajpm.v10i2.3559

Kriteria pencapaian menurut

Nurpratiwi, Sriwanto, \& Serjanti (2015), yaitu:

- Jika mencapai $N<55 \%$, maka dikategorikan tidak baik

- Jika mencapai $55 \%<N \leq 70 \%$, maka dikategorikan kurang baik
- Jika mencapai $70 \%<N \leq 85 \%$, maka dikategorikan baik

- Jika mencapai $85 \%<N \leq$ $100 \%$, maka dikategorikan sangat baik

Pedoman penskoran untuk menganalisis aktivitas belajar siswa disajikan pada Tabel 1.

Tabel 1. Penskoran aktivitas belajar siswa

\section{Jenis}

Aktivitas

(1) visual activities

(2) oral activities

(3) activities

\section{Komponen}

Skor

- Aktivitas siswa yang tidak memperhatikan guru dan teman, tidak membaca materi 1 dan tugas pada kegiatan pembelajaran

- Aktivitas siswa yang tidak memperhatikan guru/teman, hanya membaca materi 2 dan soal pada kegiatan pembelajaran

- Aktivitas siswa yang memperhatikan, membaca terlihat pada kegiatan 3 pembelajaran,

- Aktivitas siswa tidak mengajukan pertanyaan, tidak mengemukakan pendapat pada 1 kegiatan pembelajaran

- Aktivitas siswa ada yang mengajukan pertanyaan, mengemukakan pendapat dan 2 ada yang tidak karena mendapat respon sedikit dari siswa yang lain pada kegiatan pembelajaran

- Aktivitas siswa ada yang mengajukan pertanyaan, mengemukakan pendapat pada 3 kegiatan pembelajaran dalam serta mendapat respon dari siswa lain

(3) - Aktivitas siswa tidak mendengarkan guru dan siswa yang lain misal saat presentasi 1 tidak terlihat pada kegiatan pembelajaran

- Aktivitas siswa tidak mendengarkan guru/ siswa yang lain misal saat presentasi 2 pada kegiatan pembelajaran

- Aktivitas siswa mendengarkan guru dan siswa yang lain misal saat presentasi pada 3 kegiatan pembelajaran

\begin{tabular}{cll} 
(4) writing & - Aktivitas siswa tidak menulis, mengerjakan pada kegiatan pembelajaran & 1 \\
\cline { 2 - 3 } activities & - Aktivitas siswa ada yang menulis, mengerjakan dan ada yang tidak pada kegiatan & 2
\end{tabular} pembelajaran

- Aktivitas siswa yang menulis, mengerjakan pada kegiatan pembelajaran 3

(5) - Aktivitas siswa yang tidak menggambar garis bilangan pada materi bilangan bulat 1

drawing dan pecahan pada kegiatan pembelajaran

activities - Aktivitas siswa yang menggambar garis bilangan pada materi bilangan bulat dan 2 pecahan dan ada yang tidak pada kegiatan pembelajaran

- Aktivitas siswa yang menggambar garis bilangan pada materi bilangan bulat dan 3 pecahan pada kegiatan pembelajaran

\begin{tabular}{|c|c|c|}
\hline $\begin{array}{l}\text { (6) motor } \\
\text { activities }\end{array}$ & $\begin{array}{l}\text { - Aktivitas siswa tidak menemukan jawaban dan tidak berdiskusi pada kegiatan } \\
\text { pembelajaran }\end{array}$ & 1 \\
\hline & $\begin{array}{l}\text { - Aktivitas siswa ada yang menemukan jawaban ada yang tidak dan ada yang } \\
\text { berdiskusi ada yang tidak pada kegiatan pembelajaran }\end{array}$ & 2 \\
\hline & - Aktivitas siswa menemukan jawaban dan berdiskusi pada kegiatan pembelajaran & 3 \\
\hline $\begin{array}{l}\text { (7) } \text { mental } \\
\text { activities }\end{array}$ & $\begin{array}{l}\text { - Aktivitas siswa tidak menanggapi, memahami, memecahkan soal yang diberi pada } \\
\text { kegiatan pembelajaran }\end{array}$ & 1 \\
\hline & $\begin{array}{l}\text { - Aktivitas siswa ada yang menanggapi, memahami, memecahkan soal dan ada yang } \\
\text { tidak pada kegiatan pembelajaran }\end{array}$ & 2 \\
\hline & $\begin{array}{l}\text { - Aktivitas siswa yang menanggapi, memahami, memecahkan soal dan pada } \\
\text { kegiatan pembelajaran }\end{array}$ & 3 \\
\hline
\end{tabular}


DOI: https://doi.org/10.24127/ajpm.v10i2.3559

\begin{tabular}{clc}
\hline $\begin{array}{c}\text { Jenis } \\
\text { Aktivitas }\end{array}$ & \multicolumn{1}{c}{ Komponen } & Skor \\
\hline $\begin{array}{c}\text { (8) } \\
\text { emotional } \\
\text { activities }\end{array}$ & $\begin{array}{l}\text { - Aktivitas siswa yang tidak berani, antusias, semangat, senang, peduli dan merasa } \\
\text { gugup pada kegiatan pembelajaran }\end{array}$ & 1 \\
\cline { 2 - 3 } & $\begin{array}{l}\text { - Aktivitas siswa yang terlihat berani, antusias, semangat, senang, peduli maupun } \\
\text { tidak dan merasa gugup dan tidak pada kegiatan pembelajaran pada kegiatan }\end{array}$ & 2 \\
& $\begin{array}{l}\text { pembelajaran, memberi respon sedikit dengan suasana ramai } \\
\end{array}$ & - Aktivitas siswa yang berani, antusias, semangat, senang, peduli tidak gugup pada \\
& kegiatan pembelajaran & 3 \\
\hline Skor maksimal: & & 24 \\
\hline
\end{tabular}

\section{HASIL DAN PEMBAHASAN}

Berdasarkan penelitian yang telah dilaksanakan, maka akan disajikan hasil dari penelitian secara teaching experimental. Hasil pengamatan observer terhadap aktivitas belajar siswa selama proses pembelajaran berlangsung menggunakan lembar observasi yang dilakukan oleh observer. Observer menilai 2 kelompok yang terbentuk dari 9 orang siswa, 3 siswa laki-laki dan 6 siswa perempuan. Data digunakan untuk menginformasi aktivitas belajar apa saja siswa yang sedang dilakukan siswa selama proses pembelajaran berlangsung. Aktivitas yang dinilai yakni aktivitas yang meliputi 8 indikator dari aktivitas belajar siswa. Hal ini dilakukan pada pertemuan pertama sampai pertemuan ketiga. Hasil yang diperoleh ditunjukkan pada Tabel 2.

Tabel 2. Hasil Ketercapaian Observasi Setiap Aktivitas Belajar Siswa

\begin{tabular}{|c|c|c|c|c|c|c|c|c|c|c|c|c|}
\hline \multirow{3}{*}{ No. } & \multirow{3}{*}{$\begin{array}{c}\text { Jenis } \\
\text { Aktivitas }\end{array}$} & \multicolumn{9}{|c|}{ Skor Ketercapaian (\%) } & \multirow{3}{*}{$\begin{array}{c}\text { Rata-rata } \\
\text { Ketercapai } \\
\text { an }\end{array}$} & \multirow{3}{*}{$\begin{array}{l}\text { Kriteria } \\
\text { Capaian }\end{array}$} \\
\hline & & \multicolumn{3}{|c|}{ Pertemuan 1} & \multicolumn{3}{|c|}{ Pertemuan 2} & \multicolumn{3}{|c|}{ Pertemuan 3} & & \\
\hline & & 0-1 & O-2 & $\begin{array}{c}\text { Rata- } \\
\text { rata }\end{array}$ & O-1 & O-2 & $\begin{array}{c}\text { Rata- } \\
\text { rata }\end{array}$ & 0-1 & O-2 & $\begin{array}{c}\text { Rata- } \\
\text { rata }\end{array}$ & & \\
\hline 1 & Visual & 100 & 100 & 100 & 100 & 100 & 100 & 66,67 & 100 & 83,33 & 94,44 & $\begin{array}{c}\text { Sangat } \\
\text { Baik }\end{array}$ \\
\hline 2 & Oral & 66,67 & 66,67 & 66,67 & 66,67 & 66,67 & 66,67 & 100 & 66,67 & 83,33 & 72,22 & Baik \\
\hline 3 & Listening & 100 & 100 & 100 & 100 & 100 & 100 & 66,67 & 100 & 83,33 & 94,44 & $\begin{array}{c}\text { Sangat } \\
\text { Baik }\end{array}$ \\
\hline 4 & Writing & 66,67 & 100 & 83,33 & 66,67 & 100 & 83,33 & 66,67 & 100 & 83,33 & 83,33 & Baik \\
\hline 5 & Drawing & 66,67 & 100 & 83,33 & 66,67 & 100 & 83,33 & 66,67 & 66,67 & 66,67 & 77,78 & Baik \\
\hline 6 & Motor & 100 & 66,67 & 83,33 & 100 & 66,67 & 83,33 & 100 & 66,67 & 83,33 & 83,33 & Baik \\
\hline 7 & Mental & 66,67 & 66,67 & 66,67 & 100 & 100 & 100 & 66,67 & 100 & 83,33 & 83,33 & Baik \\
\hline 8 & Emotional & 100 & 66,67 & 83,33 & 100 & 100 & 100 & 100 & 66,67 & 83,33 & 88,89 & $\begin{array}{c}\text { Sangat } \\
\text { Baik }\end{array}$ \\
\hline
\end{tabular}

Berdasarkan Tabel 2 dapat dilihat bahwa aktivitas siswa dari pertemuan pertama sampai ketiga ada yang naik dan turun. Aktivitas siswa yang naik adalah aktivitas oral, mental, dan emosi. Sedangkan aktivitas siswa yang turun yaitu aktivitas visual, listening, dan drawing. Sedangkan yang konsisten 
adalah aktivitas writing dan motor. Lebih lanjut jika melihat rata-rata dari pertemuan pertama sampai ketiga,maka aktivitas siswa dikategorikan baik dan sangat baik. Aktivitas visual, listening, dan emotional dikategorikan sangat baik. Sedangkan oral, writing, drawing, motor, mental activities dikategorikan baik. Selanjutnya dibahas secara lebih lengkap untuk masing-masing aktivitas.

\section{a. Visual Activities}

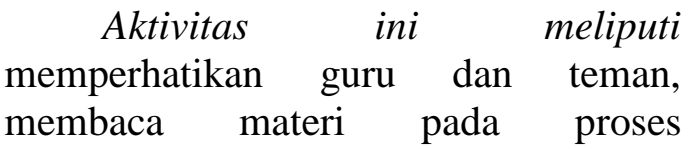
pembelajaran. Visual activities mendapat persentase sebesar $100 \%$ pada pertemuan pertama dan kedua artinya semua kelompok memenuhi indikator yang ada di lembar observasi, pertemuan ketiga mendapat persentase sebesar $83,33 \%$ artinya ada beberapa siswa yang tidak memenuhi indikator di visual activities namun sebagian besar lainnya memenuhi. Dari pertemuan pertama, kedua persentasenya stabil sebesar $100 \%$ dan mengalami penurunan sebesar $16,67 \%$ di pertemuan ketiga. Salah satu contoh visual activities yang terjadi saat pembelajaran berlangsung, yakni memperhatikan guru dan membaca materi di dalam catatan mereka. Salah satu bentuk visual activities disajikan pada Gambar 1.

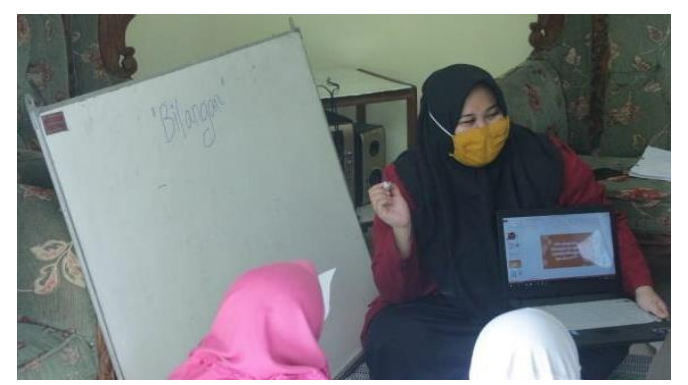

Gambar 1. Visual activities saat pembelajaran
Pada visual activities banyak siswa yang sudah memenuhi kriteria pada indikator visual activities. Artinya tingkat ketercapaian dari pembelajaran saat melakukan visual activities sangat baik. Hal ini sejalan dengan penelitian (Saraswati \& Djazari, 2018; Zulfa \& Zahroul, 2016) menyatakan bahwa siswa saat memperhatikan guru memiliki persentase yang meningkat dan sangat aktif.

Untuk temuan atau catatan dari observer yang tidak ada di pernyataan lembar obeservasi yakni siswa memperhatikan antar teman saat menyampaikan hasil pekerjaanya. Artinya dapat dikatakan penilaian didapat saat siswa memperhatikan guru dan teman saat berkelompok selama proses pembelajaran berlangsung. Hasil ini sesuai dengan peneliti terdahulu yang menyatakan bahwa visual activities meliputi: membaca materi, memperhatikan guru dalam menyampaikan materi ((Nuraini, Fitriani, \& Fadhilah, 2018; (Paizaluddindan \& Ermalinda, 2014)).

\section{b. Oral Activities}

Aktivitas oral meliputi aktivitas mengajukan pertanyaan, mengemukakan pendapat, dan mendapat respon dari siswa lain pada proses pembelajaran. Oral activities mendapat persentase sebesar $66,67 \%$ pada pertemuan pertama dan kedua, pertemuan ketiga mendapat persentase sebesar 83,33\%. Dari pertemuan pertama, kedua persentasenya stabil sebesar $66,67 \%$ dan mengalami kenaikan sebesar $16,66 \%$ di pertemuan ketiga. Salah satu contoh oral activities yang terjadi, yakni mengajukan pertanyaan, mengemukakan pendapat, mendapat respon dari siswa lain. Salah satu oral activities ditunjukkan oleh Gambar 2. 
DOI: https://doi.org/10.24127/ajpm.v10i2.3559

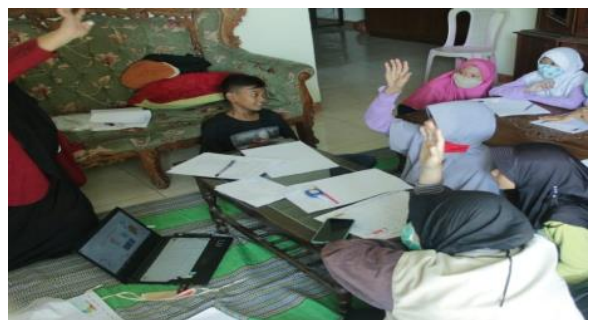

Gambar 2. Oral activities saat pembelajaran

Pada oral activities banyak siswa yang sudah memenuhi kriteria pada indikator oral activities. Artinya tingkat ketercapaian dari pembelajaran saat melakukan oral activities baik. Hasil ini sesuai dengan penelitian (Rahmadani N., 2018; Zulfa \& Zahroul, 2016) menyatakan bahwa siswa saat guru bertanya dan menyampaikan pendapat kepada siswa memiliki persentase sangat aktif.

Pada oral activities yang terjadi saat metode Brainstorming Tipe Round Robin, yakni: saat siswa mengajukan pertanyaan kepada guru apabila dirasa ada yang kurang jelas, siswa mengemukakan pendapat dalam setiap kelompok diskusinya sendiri. Artinya dapat dikatakan penilaian didapat saat siswa merasa ada yang ingin ditanyakan dan akan mengemukakan pendapatnya.

\section{c. Listening Activities}

Berdasarkan hasil analisis pada tabel 2 dapat dilihat bahwa terdapat siswa yang memenuhi indikator pada listening activities, yakni mendengarkan guru dan siswa pada proses pembelajaran. Listening activities mendapat persentase sebesar $100 \%$ pada pertemuan pertama dan kedua artinya semua kelompok memenuhi indikator yang ada di lembar observasi, pertemuan ketiga mendapat persentase sebesar $83,33 \%$ artinya ada beberapa siswa yang tidak memenuhi indikator di listening activities namun sebagian besar lainnya memenuhi. Dari pertemuan pertama, kedua persentasenya stabil sebesar $100 \%$ dan mengalami penurunan sebesar $16,67 \%$ di pertemuan ketiga. Salah satu contoh listening activities yang terjadi saat pembelajaran berlangsung, yakni mendengarkan penjelasan guru. Salah satu listening activities ditunjukkan oleh Gambar 3.

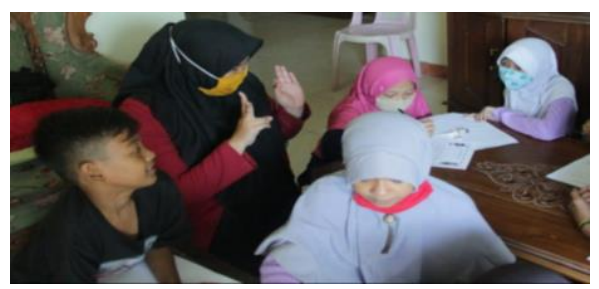

Gambar 3. Listening activities saat pembelajaran

Pada listening activities banyak siswa yang sudah memenuhi kriteria pada indikator listening activities. Artinya tingkat ketercapaian dari pembelajaran saat melakukan listening activities sangat baik. Hal ini berbeda dengan hasil penelitian (Nuraini, Fitriani, \& Fadhilah, 2018; Ulfaira, Jamaludin, \& Septiwiharti, 2014) menyatakan bahwa siswa saat mendengarkan penjelasan guru dan mendengarkan saat teman menyampaikan pendapatnya memiliki persentase yang cukup aktif dan dikategorikan baik.

Pada listening activities yang terjadi saat metode Brainstorming Tipe Round Robin, yakni penilaian didapat saat siswa mendengarkan penjelasan guru dan teman mengenai materi dan saat berdiskusi dengan kelompoknya pada pembelajaran yang berlangsung. Hasil listening activities sesuai penelitian Nurhidayah (2015) meliputi: mendengarkan pendapat teman kelompok, mendengarkan penjelasan guru, dan mendengarkan pendapat kelompok lain mendapatkan persentase sebesar $68,44 \%$ yang dikategorikan baik. 
DOI: https://doi.org/10.24127/ajpm.v10i2.3559

\section{d. Writing Activities}

Writing activities meliputi aktivitas menulis dan mengerjakan LKK pada proses pembelajaran. Writing activities mendapat persentase sebesar $83,33 \%$ pada pertemuan pertama, kedua, dan ketiga artinya ada beberapa siswa yang tidak memenuhi indikator di writing activities namun sebagian besar lainnya memenuhi. Dari pertemuan pertama, kedua, dan ketiga persentasenya stabil sebesar 83,33\%. Salah satu contoh writing activities yang terjadi saat pembelajaran berlangsung, yakni menuliskan hasil jawabannya. Contoh siswa saat mengerjakan soal di depan dan menuliskan hasil jawabannya ditunjukkan oleh Gambar 4.

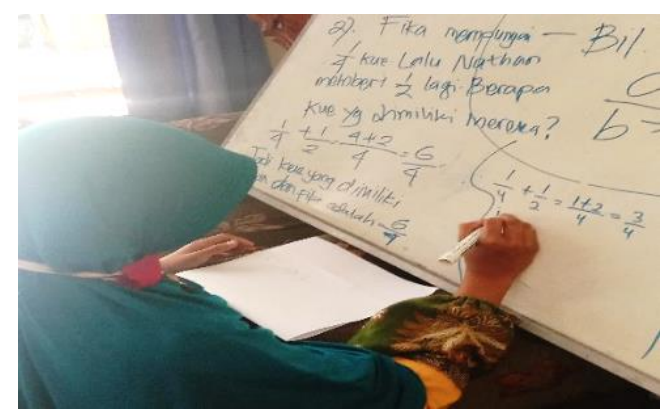

Gambar 4. Writing activities saat pembelajaran

Pada writing activities banyak siswa yang sudah memenuhi kriteria pada indikator writing activities. Artinya tingkat ketercapaian dari pembelajaran saat melakukan writing activities baik. Sedikit berbeda dengan hasil penelitian (Aliwanto, 2017; Rahmadani N., 2018) menyatakan bahwa siswa saat menulis, mengerjakan soal dalam belajar memiliki persentase yang dikategorikan cukup baik dan dikategorikan baik.

Dari setiap pertemuan yakni pertemuan pertama sampai terakhir, hasil persentase mengalami kestabilan sebesar 83,33\%. Pada writing activities yang terjadi saat metode Brainstorming Tipe Round Robin, yakni sejalan dengan hasil penelitian menurut (Azizah, 2013; Nuraini, Fitriani, \& Fadhilah, 2018) writing activities meliputi : mengerjakan soal atau latihan yang diberikan, menulis materi. Artinya dapat dikatakan penilaian didapat saat siswa menuliskan apa yang mereka butuhkan sebagai catatan atau jawaban yang paling benar dari hasil diskusi pada pembelajaran yang berlangsung.

\section{e. Drawing Activities}

Drawing activities pada penelitian ini yakni menggambar garis bilangan pada materi bilangan bulat dan menggambar ilustrasi soal pada LKK untuk materi bilangan bulat dan pecahan pada proses pembelajaran. Drawing activities mendapat persentase sebesar $83,33 \%$ pada pertemuan pertama dan kedua, pada pertemuan ketiga mendapat persentase sebesar 66,67\%. Dari pertemuan pertama dan kedua persentasenya stabil sebesar $83,33 \%$, dan mengalami penurunan sebesar $16,67 \%$ di pertemuan ketiga. Salah satu contoh drawing activities yang terjadi saat pembelajaran berlangsung, yakni menggambarkan garis bilangan dari ilustrasi soal di LKK. Berikut contoh hasil pekerjaan siswa saat menggambarkan garis bilangan dari hasil pekerjaannya disajikan pada Gambar 5.

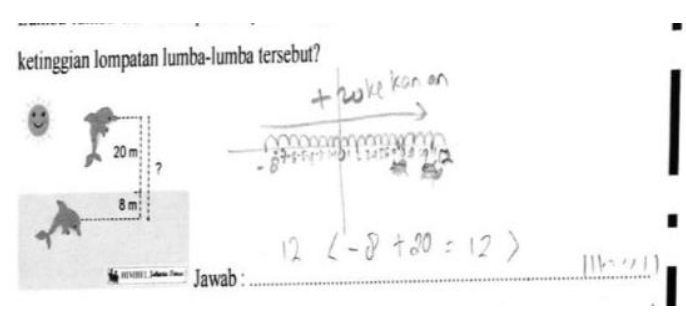

Gambar 5. Drawing activities saat pembelajaran

Pada drawing activities banyak siswa yang sudah memenuhi kriteria pada indikator drawing activities. 
Artinya tingkat ketercapaian dari pembelajaran saat melakukan drawing activities baik. Sedikit berbeda dengan hasil penelitian Aliwanto (2017) menyatakan bahwa siswa saat menggambar sesuatu terkait dengan materi yang dipelajari dan dibahas memiliki persentase sebesar $60,67 \%$ yang dikategorikan cukup baik.

Pada drawing activities yang terjadi saat metode Brainstorming Tipe Round Robin, yakni penilaian didapat saat siswa misal: menggambar garis bilangan, ilustrasi pada soal, contoh dari pecahan dalam bentuk lingkaran atau persegi pada pembelajaran yang berlangsung. Sesuai dengan referensi, drawing activities meliputi : kegiatan menggambar, membuat grafik (Aliwanto, 2017). Dalam penelitian ini siswa menggambar garis bilangan, ilustrasi pecahan, mengaplikasikan dari soal cerita lalu di gambar garis bilangan atau ilustrasi pemodelannya.

\section{f. Motor Activities}

Berdasarkan hasil analisis pada tabel 2 dapat dilihat bahwa terdapat siswa yang memenuhi indikator pada motor activities, yakni menemukan jawaban dan berdiskusi pada proses pembelajaran. motor activities mendapat persentase sebesar 83,33\% pada pertemuan pertama, kedua, dan ketiga artinya ada beberapa siswa yang tidak memenuhi indikator di motor activities namun sebagian besar lainnya memenuhi. Dari pertemuan pertama, kedua, dan ketiga persentasenya stabil sebesar 83,33\%. Salah satu contoh motor activities yang terjadi saat pembelajaran berlangsung, yakni berdiskusi dengan kelompoknya dan tiap kelompok menemukan jawaban. Salah satu bentuk motor activities ditunjukkan oleh Gambar 6.

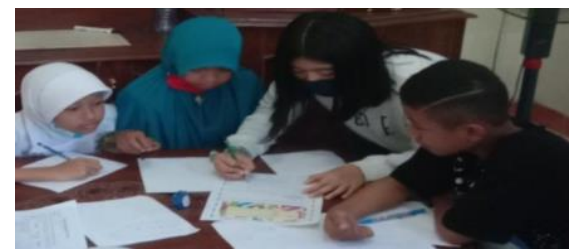

Gambar 6. Motor activities saat pembelajaran

Pada motor activities banyak siswa yang sudah memenuhi kriteria pada indikator motor activities. Artinya tingkat ketercapaian dari pembelajaran saat melakukan motor activities baik. Sejalan dengan hasil penelitian (Ayuwanti, 2017; Mufidah, Effendi, \& Purwanti, 2013) menyatakan bahwa siswa saat menemukan jawaban dan berdiskusi memiliki persentase sebesar 93,55\% yang dikategorikan baik dan mencapai target keberhasilan dari penelitiannya. Dari setiap pertemuan yakni pertemuan pertama sampai terakhir, hasil persentase mengalami kestabilan yakni sebesar 83,33\% pada setiap pertemuan.

Pada motor activities yang terjadi saat metode Brainstorming Tipe Round Robin, yakni penilaian didapat saat siswa berhasil menemukan jawaban dari LKK yang diberikan, menemukan solusi dari apa yang mereka diskusikan dengan kelompoknya pada pembelajaran yang berlangsung. Sesuai dengan referensi, motor activities meliputi: menyelesaikan persoalan, menemukan jawaban, menyelesaikan masalah (Ayuwanti, 2017; Azizah, 2013).

\section{g. Mental Activities}

Mental activities meliputi aktivitas menanggapi, memahami, dan memecahkan soal pada proses pembelajaran. Mental activities mendapat persentase sebesar $66,67 \%$ pada pertemuan pertama, pada pertemuan kedua mendapat persentase sebesar $100 \%$, dan pertemuan ketiga 
mendapat persentase sebesar 83,33\%. Dari pertemuan pertama persentasenya $66,67 \%$ mengalami peningkatan pada pertemuan kedua sebesar 33,33\% dan mengalami penurunan pada pertemuan ketiga sebesar 16,67\%. Salah satu contoh mental activities yang terjadi saat pembelajaran berlangsung, yakni untuk memecahkan soal yang ada di LKK dan membuat keputusan bersama di akhir pembelajaran. Salah satu aktivitas mental disajikan pada Gambar 7.

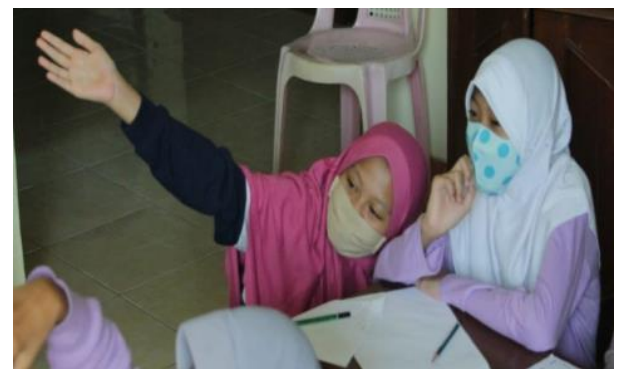

Gambar 7. Mental activities saat pembelajaran

Pada mental activities banyak siswa yang sudah memenuhi kriteria pada indikator mental activities. Artinya tingkat ketercapaian dari pembelajaran saat melakukan mental activities baik. Berbeda dengan hasil penelitian (Ayuwanti, 2017; Rahmadani N., 2018) menyatakan bahwa siswa saat menanggapi, memahami, memecahkan soal pada proses pembelajaran yang dikategorikan sudah cukup baik dan baik dalam menanggapi, memecahkan soal pada proses pembelajaran.

Pada mental activities yang terjadi saat metode Brainstorming Tipe Round Robin, yakni siswa dapat memecahkan soal di LKK bersama kelompoknya, siswa menanggapi pendapat dari teman sekelompoknya, siswa bersama-sama membuat keputusan bersama dari hasil kerja kelompok yang telah dilakukan. Sesuai referensi, mental activities meliputi: menanggapi pendapat yang lain, memecahkan soal, membuat keputusan bersama atau kesimpulan berjalan dengan kategori baik pula (Dreyfus, 2018; Mufidah, Effendi, \& Purwanti 2013; Ulfaira, Jamaludin, \& Septiwiharti, 2014). Penekanan aktivitas individu siswa dalam kelompok dapat meningkatkan keterlibatan dalam pembelajaran siswa bisa dikatakan berdiskusi dengan kelompoknya masing-masing sesuai dengan hasil Căprioară \& Frunză (2013).

\section{h. Emotional Activities}

Aktivitas ini melikupi memiliki rasa berani, antusias, semangat, senang, peduli, dan tidak gugup pada proses pembelajaran. Emotional activities mendapat persentase sebesar 83,33\% pada pertemuan pertama dan ketiga, dan pertemuan kedua mendapat persentase sebesar $100 \%$. Dari pertemuan pertama persentasenya $83,33 \%$ mengalami peningkatan pada pertemuan kedua sebesar $16,67 \%$ dan mengalami penurunan pada pertemuan ketiga sebesar $16,67 \%$ juga. Salah satu contoh emotional activities yang terjadi saat pembelajaran berlangsung, yakni berani untuk menjawab pertanyaan guru dan senang saat antar siswa peduli untuk bekerjasama menjawab soal dengan senang dan semangat. Emotional activities, salah satunya ditunjukkan oleh Gambar 8.

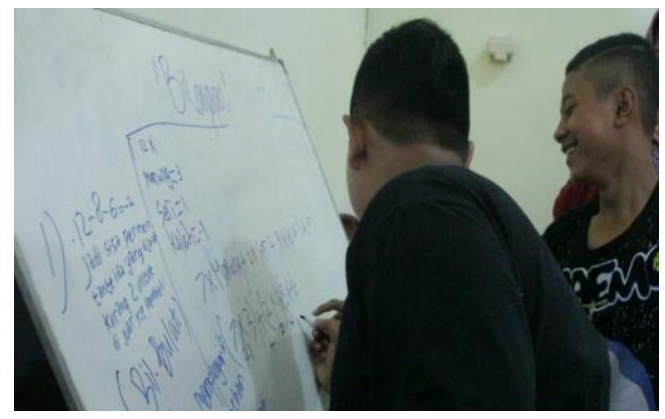

Gambar 8. Emotional activities saat pembelajaran 
DOI: https://doi.org/10.24127/ajpm.v10i2.3559

Pada emotional activities banyak siswa yang sudah memenuhi kriteria pada indikator emotional activities. Artinya tingkat ketercapaian dari pembelajaran saat melakukan emotional activities sangat baik. Berbeda dengan hasil penelitian (Ayuwanti, 2017; Nuraini, Fitriani, \& Fadhilah, 2018) menyatakan bahwa siswa saat memiliki rasa berani, antusias, semangat, senang, peduli, tidak gugup pada proses pembelajaran memiliki persentase sebesar $61,28 \%$ yang dikategorikan sudah cukup baik dan 80,56\% dikategorikan sangat aktif. Jadi sejalan dengan hasil penelitian Nuraini, Fitriani, \& Fadhilah (2018) bahwa emotional activities berjalan dengan sangat baik dan sangat aktif.

Pada emotional activities yang terjadi saat metode Brainstorming Tipe Round Robin, yakni penilaian didapat saat siswa yang dari awal pembelajaran menunjukkan rasa semangat untuk belajar, antusias mengikuti pembelajaran, dan memiliki rasa percaya diri untuk bertanya atau menjawab pertanyaan yang diberikan, dan memiliki rasa kebangaan saat menjawab dengan benar pada pembelajaran yang berlangsung. Emotional activities meliputi: berperilaku baik selama proses pembelajaran atau aktif, bersama-sama semangat menyimpulkan hasil diskusi sebagai apresiasi dari teman dan guru, berani berpendapat dari soal yang diberikan, mempresentasikan hasil jawabannya di depan kelas, saling memotivasi antar teman untuk menyelesaikan permasalahan, kecerdasan emosional (Coto \& Mora, 2019; Tevdovska, 2017; Ulfaira, Jamaludin, \& Septiwiharti, 2014).

Berdasar hasil penelitian bahwa metode Brainstorming Tipe Round Robin sangat baik dalam meningkatkan aktivitas siswa dalam proses pembelajaran matematika, lebih khusus pada aktivitas oral, mental, dan emosi sehingga dapat dijadikan salah satu alternatif dan bahan pertimbangan oleh guru dalam memvariasi metode pembelajaran untuk meningkatkan aktivitas belajar siswa, dan untuk dapat terus dikembangkan di sekolah agar siswa tidak merasa bosan. Hasil ini dapat dijadikan rujukan dalam menyusun bahan ajar atau memilih/membuat media pembelajaran.

\section{KESIMPULAN DAN SARAN}

Hasil analisis observasi aktivitas belajar siswa ketika proses pembelajaran dengan penerapan metode Brainstorming Tipe Round Robin berlangsung pada materi bilangan bulat dan pecahan dapat dilihat bahwa ratarata persentase ketercapaian pada setiap pertemuan dari tiap kelompok mengalami penurunan, stabil, dan peningkatan pada akhir aktivitas belajar siswa yang didapat dalam kategori baik serta kategori sangat baik.

Aktivitas siswa yang naik adalah aktivitas oral, mental, dan emosi. Sedangkan aktivitas siswa yang turun yaitu aktivitas visual, listening, dan drawing. Sedangkan yang konsisten adalah aktivitas writing dan motor. Aktivitas dikategorikan sangat baik pada aktivitas visual, mendengarkan, dan emosional. Sedangkan pada aktivitas oral, menulis, emosi, motor, dan menggambar dikategorikan baik.

Penelitian ini terbatas pada aktivitas belajar siswa dengan metode Brainstorming Tipe Round Robin. Sehingga masih sangat terbuka bagi penelitian lanjutan dengan metode ini untuk mengkaji proses berpikit tingkat tinggi, komunikasi dan hasil belajar siswa. 
DOI: https://doi.org/10.24127/ajpm.v10i2.3559

\section{DAFTAR PUSTAKA}

Aliwanto. (2017). Analisis Aktivitas Belajar. Jurnal Konseling, 3(1), 64-71.

Amin, D. (2017). Penerapan Metode Curah Gagasan (Brainstorming) Untuk Meningkatkan Kemampuan Mengemukakan Pendapat Siswa. Jurnal Pendidikan Sejarah, 5(2), 1. https://doi.org/10.21009/jps.052.01

Ayu, N. M., Yusmin, E., \& BS., D. A. (2019). Penerapan Model Pembelajaran Kooperatif Tipe Round Robin Pada Materi Bangun Datar Segi Empat di SMP Negeri 3 Pontianak. Jurnal Pendidikan Dan Pembelajaran Khatulistiwa, 08(6), 1-6.

Ayuwanti, I. (2017). Meningkatkan Aktivitas dan Hasil Belajar Matematika Menggunakan Model Pembelajaran Kooperatif Tipe Group Investigation di SMK Tuma'ninah Yasin Metro. SAP (Susunan Artikel Pendidikan), 1(2), 105-114. https://doi.org/10.30998/sap.v1i2.1 017

Azizah, D. (2013). Penerapan Pendekatan Struktural Metode Think Pair Share (TPS) Pada Materi Lingkaran Untuk Meningkatkan Aktivitas Belajar Matematika Siswa. Delta Jurnal Ilmiah Pendidikan Matematika FKIP ..., 1(2), 115-199. Retrieved from

https://scholar.google.co.id/scholar ?start $=10 \& q=$ metode + think + pair $+s$ hare $\& h l=e n \& a s \_s d t=0,5 \# 3$

Budiyono, A., Kusumaningsih, W., \& Albab, I. U. (2019). Desain Pembelajaran Luas Lingkaran dengan Konteks Explore Dapur Berbasis Realistic Mathematics Education (RME) di Kelas VIII Sekolah Menengah Pertama
(SMP). Imajiner: Jurnal Matematika Dan Pendidikan Matematika, 1(4), 37-44. https://doi.org/10.26877/imajiner.v $1 \mathrm{i} 4.3854$

Căprioară, D., \& Frunză, V. (2013). Differentiation and Individualization in the Organization of the TeachingLearning Activities in Mathematics. Procedia - Social and Behavioral Sciences, 93, 2063-2067.

https://doi.org/10.1016/j.sbspro.20 13.10.166

Coto, M., \& Mora, S. (2019). Are there any gender differences in students' emotional reactions to programming learning activities? ACM International Conference Proceeding Series. https://doi.org/10.1145/3335595.33 35608

Dreyfus, T. (2018). Learning Through Activity - Basic research on mathematical cognition. Journal of Mathematical Behavior, 52(November 2017), 216-223. https://doi.org/10.1016/j.jmathb.20 18.04.001

Eka Fatmahwati, T. (2014). Peningkatan Kualitas Pembelajaran Matematika Melalui Pendekatan Pmri Berbantuan Media Grafis. Joyful Learning Journal, 3(1), 1723.

Eko Nugroho, B. (2016). Penerapan Model Pembelajaran Snowball Throwing Untuk Meningkatkan Aktivitas Siswa Dalam Proses Pembelajaran Serta Meningkatkan Hasil Belajar Matematika Siswa Kelas VIII SMP Pawyatan Daha 1 Kediri Materi Garis Lurus. Artikel Skripsi Universitas Nusantara PGRI Kediri, (Pendidikan), 1. 
DOI: https://doi.org/10.24127/ajpm.v10i2.3559

Hanida, T., Suryani, \& Sukmawati. (2016). Peningkatan Aktivitas Belajar Siswa Melalui Pembelajaran Tematik Di Kelas II Sekolah Dasar. Jurnal Pendidikan Dan Pembelajaran Khatulistiwa, 5(1).

Mufidah, L., Effendi, D., \& Purwanti, T. T. (2013). Penerapan Model Pembelajaran Kooperatif Tipe TPS Untuk Meningkatkan Aktivitas Belajar Siswa Pada Pokok Bahasan Matriks. Jurnal Pendidikan Matematika STKIP PGRI Sidoarjo, 1(1), 117-125.

Nuraini, N., Fitriani, F., \& Fadhilah, R. (2018). Hubungan Antara Aktivitas Belajar Siswa Dan Hasil Belajar Pada Mata Pelajaran Kimia Kelas $\mathrm{X}$ Sma Negeri 5 Pontianak. ARRAZI Jurnal Ilmiah, 6(1). https://doi.org/10.29406/arz.v6i1.9 39

Nurhidayah, D. A. (2015). Peningkatan Aktivitas Belajar Siswa Melalui Pembelajaran Kooperatif Tipe Group Investigasi Pada Materi Geometri. Jurnal Dimensi Pendidikan Dan Pembelajaran, 3(2), 43-50.

Nurpratiwi, R. T., Sriwanto, S., \& Serjanti, E. (2015). Peningkatan Aktivitas Dan Prestasi Belajar Siswa Melalui Metode Picture and Picture Dengan Media Audio Visual Pada Mata Pelajaran Geografi Di Kelas Xi Ips 2 Sma Negeri 1 Bantarkawung. Geoedukasi, 4(2), 1-9.

Paizaluddindan, \& Ermalinda. (2014). Jurnal Penelitian Pembelajaran Matematika Sekolah (JP2MS), Vol. 1, No. 1, Agustus 2017 eISSN 2581-253X. Jurnal Penelitian Pembelajaran Matematika Sekolah (JP2MS), 1(1), 212.

Rahmadani N., A. I. (2018).
Peningkatan Aktivitas Belajar Matematika Melalui Pendektan Problem Based Learning Bagi Siswa Kelas 4 SD. 241-250.

Rahmayanti, V. (2016). Pengaruh Minat Belajar Siswa dan Persepsi atas Upaya Guru dalam Memotivasi Belajar Siswa terhadap Prestasi Belajar Bahasa Indonesia Siswa SMP di Depok. SAP (Susunan Artikel Pendidikan), 1(2), 206216.

https://doi.org/10.30998/sap.v1i2.1 027

Reeve, J. (2012). A self-determination theory perspective on student engagement Handbook of research on student engagement (pp. 149172): Springer.

Rohmah, M. S., \& Herdiman, I. (2017). Penerapan Pendekatan Brainstorming Round Robin Koneksi Matematik Serta Kemandirian Belajar Siswa. VI(2), 91-100.

Ruíz, A. A. B. (2015). Improving Students' Descriptive Speaking Competence by Using Cue Cards at the Grade VIII 2 of Public Junior High School 03 Bengkulu City. Center of Language Innovation Journal of Linguistics and Language Teaching, 3(2), 5467.

Saraswati, N. F., \& Djazari, M. (2018). Implementasi Metode Pembelajaran Small Group Discussion Untuk Meningkatkan Aktivitas Belajar Pada Kompetensi Dasar Jurnal Penyesuaian Siswa Kelas X Akuntansi SMK Muhammadiyah Kretek Tahun Ajaran 2017/2018. Jurnal Pendidikan Akuntansi Indonesia, $X V I(2)$.

Sheng, Y. (2019). Experimental Teaching Platform. 336(Icsshe 19), 
DOI: https://doi.org/10.24127/ajpm.v10i2.3559

412-416.

Srinalia, S. (2015). Faktor-Faktor Penyebab Rendahnya Kinerja Guru Dan Korelasinya Terhadap Pembinaan Siswa: Studi kasus di SMAN 1 Darul Imarah Aceh Besar. Jurnal Ilmiah Didaktika, 15(2), 193. https://doi.org/10.22373/jid.v15i2. 580

Tevdovska, E. S. (2017). The Impact of Emotional Intelligence in the Context of Language Learning and Teaching. SEEU Review, 12(1), 125-134.

https://doi.org/10.1515/seeur-20170009

Trowler, V. (2010). Student engagement literature review. The Higher Education Academy, 11, 115.

Ulfaira, Jamaludin, \& Septiwiharti. (2014). Meningkatkan Aktivitas Belajar Pada Siswa Kelas III di SD Inpres Marantale Dalam Pembelajaran Pkn Melalui Penerapan Metode Pembelajaran Role Playing. Jurnal Kreatif Tadulako Online, 3(3), 125-142.

Werdiningsih, H., \& Sari, S. R. (2016). Peningkatan Kualitas Pembelajaran Melalui Penerapan Metoda Pembelajaran Yang Terintegrasi (Integrated Lesson Learned) Dari Mata Kuliah Yang Serumpun. Modul, $\quad 16(1), \quad 55$. https://doi.org/10.14710/mdl.16.1. 2016.55-66

Widayanti, L. (2013). Peningkatan Aktivitas Belajar dan Hasil Belajar Siswa dengan Metode Problem Based Learning pada Siswa Kelas VIIA MTs Negeri Donomulyo Kulon Progo Tahun Pelajaran 2012/2013. Jurnal Fisika Indonesia, XVII(April), 32-35.
Zulfa, N., \& Zahroul, C. F. (2016). Penerapan Metode Bermain Peran untuk Meningkatkan Aktivitas dan Hasil Belajar Siswa Kelas V pada Mata Pelajaran IPS Pokok Bahasan Jenis-jenis Usaha Ekonomi di SDN Ngadiluwih 02 Kediri. Jurnal Pedagogi, 2(3), 1-8. Retrieved from http://journal.umsurabaya.ac.id/index.php/Pedagogi /article/viewFile/533/872 